\title{
The Influence of Service Quality, Brand Image and Customer Relationship Management (CRM) on Customer Loyalty of Mini Market in East Bekasi
}

\author{
Resti Hardini \\ \{resti.hardini@civitas.unas.ac.id\}, Nasional University, Jakarta, Indonesia.
}

\section{Muhammad Lutfi Rizaldi}

\{lutfirizaldi21@gmail.com\}, Nasional University, Jakarta, Indonesia.

\section{Haris Maupa}

\{harismaupa1959@gmail.com\}, Faculty of Economics and Business, Hasanuddin University, Makassar, Indonesia.

\section{Dian Anggraece Sigit Parawansa}

\{dianparawansa62@gmail.com\}, Faculty of Economics and Business, Hasanuddin University, Makassar, Indonesia.

\section{Nurdjannah Hamid}

\{nununghamid17@gmail.com\}, Faculty of Economics and Business, Hasanuddin University, Makassar, Indonesia.

\begin{abstract}
The Influence of Service Quality, Brand Image and Customer Relationship Management on customer loyalty of mini market in Pedurenan, East Bekasi are objectives of this study. In this study using primary data by distributing questionnaires sample used was 100 respondents. Results of calculations using multiple regression methods obtained by results of a standardized regression, namely $\mathrm{Y}=3.316+0.338 \mathrm{X} 1+0.298 \mathrm{X} 2+0.222 \mathrm{X} 3$. Service Quality variable (X1) gave largest contribution of 0.338 and Brand Image variable contributed 0.928 and CRM contributed 0.222 to Loyalty. F test results showed that independent variables used in this study were able to explain variation of dependent variable changes namely Loyalty so it can be stated that model developed in this study was feasible. Independent variables have a significant and positive influence on loyalty. $\mathrm{R}$ square value shows that percentage of independent variables on Loyalty with R square value obtained by $50.2 \%$.
\end{abstract}

Keywords:

Service Quality, Brand Image, Customer Relationship Management, Loyalty

Article Received: 18 October 2020, Revised: 3 November 2020, Accepted: 24 December 2020

\section{Introduction}

Customer Loyalty has an important role in a company, retaining customers means maintaining company's survival. Consumer loyalty is very determining survival of a company, therefore company must maintain a good relationship with consumers so consumers will be loyal to company.

In realizing customer loyalty can be influenced by service quality. Companies must provide quality service because service quality can affect customer loyalty (Mulyaningsih, 2013). In addition, Loyalty can also be influenced by brand image. More competitors in self-service industry it is expected each company will build a brand image.

Implementing right marketing strategy now requires a management system to foster customer relationships, including implementing a Customer Relationship Management (CRM) system. With existence of CRM a stronger relationship can be established between company and customer. Building relationships with customers has goal of forming loyal customers for company in long run so as to realize customer loyalty. 
The application of CRM in order to foster a good relationship between company and customers can be done through several activities, one of which is making member card facilities to its customers (Kalalo, 2014). Member card is a card is usually used for various purposes related to membership of an organization, company, club or a smaller association.

There are many forms of minimarket retail, one of which is mini market in East Bekasi is a minimarket network provides basic needs and daily needs. As time went on coupled with emergence of new minimarkets, situation of minimarket itself began to be shifted. Number of minimarkets with various market strategies used makes minimarket have to work even harder to stay afloat inworld of trade. The company of this minimarket in maintaining customers applies a Customer Relationship Management (CRM) system to create an mini market card member card facility works with Bank from 2008. Goal of minimarket is to implement member cards so customers can be loyal to company. Function of minimarket cards is to ensure convenience, comfort and practicality of consumers in shopping.

It was said there was intense competition in minimarket services category. Minimarket in its business activities faces competitors of same type who fight overcame customers. Following are Top Brand Index minimarket categories.

Table 1. Top Brand Index in Minimarket Category

\begin{tabular}{cccccc}
\hline \multirow{2}{*}{ BRAND } & $\mathbf{2 0 1 2}$ & $\mathbf{2 0 1 3}$ & $\mathbf{2 0 1 4}$ & $\mathbf{2 0 1 5}$ & $\mathbf{2 0 1 6}$ \\
\hline A & $51,7 \%$ & $48,8 \%$ & $52,1 \%$ & $52,9 \%$ & $46,4 \%$ \\
B & $36,9 \%$ & $43,3 \%$ & $41,5 \%$ & $40,6 \%$ & $47,0 \%$ \\
C & $3,1 \%$ & $2,3 \%$ & $2,1 \%$ & - & - \\
D & $1,4 \%$ & - & - & - & - \\
\hline
\end{tabular}

Source: Top Brand Award, 2017

The mini market B, which was established from beginning in Indonesia, seems unable to be a pioneer and retain its customers. Tables show that customers who are not loyal to minimarket and prefer to competitors.

\section{Literature Review}

\subsection{Service Quality}

Tjiptono and Chandra (2005:121) said Service Quality as a measure of how well level of service provided is in accordance with customer expectations.

\subsubsection{Service Quality Indicator}

Service Quality can be interpreted as an effort to meet needs and desires of consumers and accuracy of its delivery in balancing consumer expectations, Tjiptono (2007:59). Indicators in this study are: tangible; reliability; responsiveness; guarantees; empathy.

\subsection{Brand Image}

Brand image is a picture or concept of something. Thus image exists, but it is not real or cannot be described physically, because image only exists in mind. According to Tjiptono (2005: 49) brand image is a Brand Image or Brand Description, which is a description of associations and consumer beliefs about a particular brand.

\subsection{Brand Image Indicator}

The brand is a promise of seller to consistently provide certain benefits and services to buyer. According to Kotler and Armstrong (2008) measurement of brand image can be done based on aspects of a brand, namely: strength, uniqueness, and favorite.

\subsection{Customer Relationship Management (CRM)}


Alma (2011:296) said customer relationship management or commonly known as CRM is a process of obtaining, maintaining and enhancing profitable customer relationships with aim of creating customer value, so customers are satisfied and maximize profits for company obtaining in in order to obtain a comparative advantage, pay attention to product quality in order to provide excellent satisfaction for customers.

\subsection{Customer Relationship Management Indicator}

This variable is measured through Kotler and Keller indicators (2009):

1) Identify (identify customers

2) Acquire (acquiring customers),

3) Retain (retain customers)

4) Develop (get customers)

\subsection{Customer loyalty}

Ali Hasan (2008:83), customer loyalty is defined as people who buy, especially people who buy regularly and repeatedly. Customer is someone who continuously and repeatedly comes to same place to satisfy his desire to have a product or get a service and pay for product or service.

Indicators of customer loyalty by Griffin (2002:74) are:

1) Make regular repurchases

2) Show attraction of competitors

3) Recommend product to others

4) Willing to pay higher if quality is better

\subsection{Analytical Framework}

To explain relationship between service quality variables, Brand Image and Customer Relationship Management, and other variables have no effect can be seen in following analysis framework:

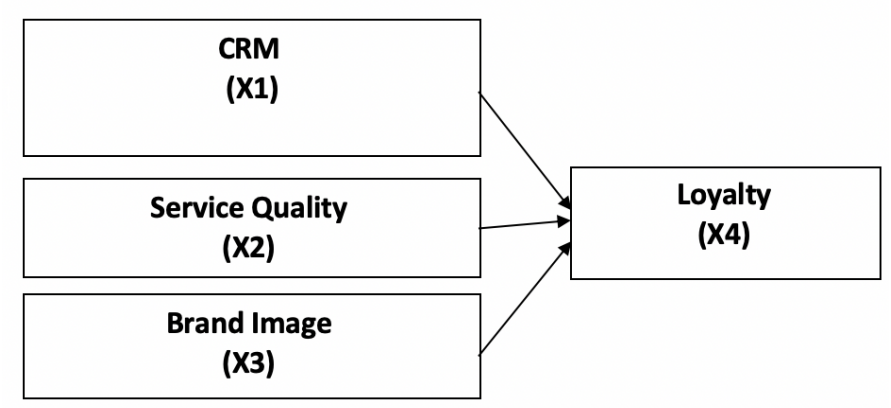

Fig. 1. Analytical Framework

\subsection{Hypothesis}

The Statistical Hypothesis stated in alternative Hypothesis (Ha) form is:

1. Ha1: $\beta 1>0$ Service Quality has a positive and significant effect on Customer Loyalty.

2. Ha2: $\beta 2>0$ Brand Image has a positive and significant effect on customer loyalty.

3. Ha3: $\beta 3>0 \mathrm{CRM}$ has a positive and significant effect on Customer Loyalty.

\section{Research Method}

\subsection{Data Type}

This study used primary data. Where primary data is data obtained directly from respondents to questionnaire in minimarket at Padurenan Village, East Bekasi using a Likert Scale.

\subsection{Research Population}

Minimarket customers in Padurenan Village, East Bekasi is population in this study.

\subsection{Research Samples}

The sampling method in this study was carried out by means of purposive sampling and quota sampling. Criteria or considerations in selecting samples based on purposive sampling, namely:

1) Criteria for Respondents who have become member card members in Minimarket, at Padurenan Village, East Bekasi.

2) Criteria for respondents who make repeat purchases at least twice in Minimarket at Padurenan Village, East Bekasi.

Determination of number of samples is unknown according to Sugiyono (2012: 79) then formula can be used as follows: 


$$
=\frac{\mathrm{Z}^{2}}{4(M o e)^{2}}
$$

Information:

$\mathrm{n} \quad=$ Number of Samples

$\mathrm{Z}=$ normal distribution level at level of $5 \%=1.96 \%$

Moe $=$ Margin of Error or maximum error rate is $10 \%$
The minimum number of samples (margin of error $10 \%$ )can be taken are:

$$
\begin{gathered}
=\frac{1,96^{2}}{4(0,10)^{2}} \\
=96,04(100 \text { respondents }) .
\end{gathered}
$$

Sampling was conducted in 8 (eight) minimarket branches located in Padurenan Village, East Bekasi

Table 2. Number of Samples by Region

\begin{tabular}{lc}
\hline \multicolumn{1}{c}{ Area } & Sample Total \\
\hline Minimarket Dukuh Zamrud & 15 \\
Minimarket Dukuh Zamrud 2 & 15 \\
Minimarket Dukuh Zamrud Utara & 15 \\
Minimarket Dukuh Zamrud Utara 2 & 15 \\
Minimarket Graha Harapan & 10 \\
Minimarket Pedurenan Indah & 10 \\
Minimarket Kampung Asem & 10 \\
Minimarket Vida & 10 \\
\multicolumn{1}{c}{ Total } & $\mathbf{1 0 0}$ \\
\hline
\end{tabular}

\subsection{Data Collection Techniques and Tools}

Data collection techniques and tools use a Likert scale

\subsection{Descriptive Analysis Method}

Descriptive analysis, which provides a descriptive or empirical description of data collected in study (Ferdinand, 2013: 72).data comes from respondents' answers to items contained in questionnaire processed by grouping and to discuss then given an explanation.

\subsection{Inferential Analysis Method}

This study inferential statistical data analysis was measured using SPSS 17.0 (Statistical Package for Social Science) software ranging from instrument testing, classical assumption tests, multiple linear regression, model feasibility tests and hypothesis testing.

\subsection{Multiple Linear Regression Analysis}

This study variable $\mathrm{X}$ has 3 independent variables, so multiple linear regression equation is used with following formula:

$$
\mathrm{Y}=\alpha+\beta 1 \mathrm{X} 1+\beta 2 \mathrm{X} 2+\beta 3 \mathrm{X} 3+\mathrm{e}
$$

Information :

$\mathrm{Y}=$ Customer Loyalty

$\alpha=$ Constant

$\beta 1+\beta 2+\beta 3=$ Coefficient of Multiple Regression

$\mathrm{X} 1=$ Service Quality

$\mathrm{X} 2=$ Brand Image

X3 = Customer Relationship Management

$\mathrm{e}=$ Error Standard

\subsection{Test Instruments}

Using validity test where in making decisions to test validity of indicators are:

1). If $r$ count (positive) $>r$ table then item or variable is valid

2 ). If $\mathrm{r}$ arithmetic (negative) $<\mathrm{r}$ table then item or variable is invalid

\subsection{Reliability Test}


This reliability test uses Cronbach Alpha $(\alpha)$ statistical test. According to Ghozali (2011: 48) decision making of a construct or variable is said to be reliable as follows:

1). If Cronbach Alpha $(\alpha)>0.60$,questionnaire used is reliable.

2). If Cronbach Alpha $(\alpha)<0.60$,questionnaire used is not reliable.

\subsection{Coefficient of Determination (R2)}

The coefficient of determination (R2) is a measure to determine suitability or accuracy of analysis model created

\subsection{Hypothesis Testing ( $T$ Test)}

This test is used to determine significance of influence of independent variables on dependent variable individually and assume that other dependent variables are constant. Significance of this influence can be estimated by comparing value of T-count at a significance of $\leq 0.05$.

4 Research Results and Discussion

\subsection{Characteristics of Respondents}

\subsubsection{Characteristics of Respondents by Gender}

Based on research data obtained from 100 respondents who filled out questionnaire, then obtained data about sex of respondents:

Table 3. Percentage of Characteristics of Respondents by Gender

\begin{tabular}{ccc}
\hline Gender & Amount & Percentage \% \\
\hline Men & 28 & $28 \%$ \\
Women & 72 & $72 \%$ \\
Total & $\mathbf{1 0 0}$ & $\mathbf{1 0 0} \%$ \\
\hline
\end{tabular}

Source: Processed data Primary, 2017

Table 3 gender of respondents shows that, majority of minimarket consumers are male sex 72 people $(72 \%)$ and men 28 people $(28 \%)$.

\subsubsection{Characteristics of Respondents by Age}

Based on research data obtained from 100 respondent who filled out questionnaire, data obtained aboutage of respondents as presented in table:

Table 4. Percentage of Characteristics of Respondents by Age

\begin{tabular}{ccc}
\hline Age & Total & Percentage $\%$ \\
\hline $17-30$ & 17 & $17 \%$ \\
$31-40$ & 35 & $35 \%$ \\
$41-50$ & 37 & $37 \%$ \\
$>50$ & 11 & $11 \%$ \\
Total & $\mathbf{1 0 0}$ & $\mathbf{1 0 0} \%$ \\
\hline
\end{tabular}

Source: Processed Data Primary, 2017

showed that respondents of age who were mostly minimarket consumers were 41-50 as many as 37 people (37\%), ages $31-40$ as many as 35 people (35\%), ages $17-30$ as many as 17 people (17\%) and aged $>50,11$ people $(11 \%)$.

\subsubsection{Characteristics of Respondents Based on Recent Education}

Based on research data obtained from 100 respondents who filled out questionnaire, then obtained data about last education of respondent as follows:

Table 5. Percentage of Characteristic of Respondent by Last Education

\begin{tabular}{ccc}
\hline $\begin{array}{c}\text { Last } \\
\text { Education }\end{array}$ & Amount & Percentage \% \\
\hline SMA & 53 & $53 \%$ \\
D3 & 12 & $12 \%$ \\
S1 & 27 & $27 \%$ \\
S2/S3 & 8 & $8 \%$ \\
Total & $\mathbf{1 0 0}$ & $\mathbf{1 0 0 \%}$ \\
\hline
\end{tabular}

Source: Processed Data Primary, 2017

The respondent's education, majority of mini market consumers, is 53 students (53\%) with high school education, 27 people with 27 degrees (27\%), 12 people with D3 education (12\%) and 8 people with Master/3 education (8\%) ). 


\subsubsection{Characteristics of Respondents by Income}

Research data obtained from 100 respondents who filled out questionnaire, it was obtained as follows:

Table 6. Percentage of Characteristics of Respondents by Income

\begin{tabular}{ccc}
\hline Revenue & Amount & $\begin{array}{c}\text { Percentage } \\
\text { \% }\end{array}$ \\
\hline < Rp. 1.000.000 & 3 & $3 \%$ \\
Rp. 1.000.000- & 22 & $22 \%$ \\
Rp. 2 .000 .000 & & \\
Rp. 2.000.000- & 34 & $34 \%$ \\
Rp. 3 .000.000 & & \\
> Rp. 3 .000.000 & 41 & $41 \%$ \\
Total & $\mathbf{1 0 0}$ & $\mathbf{1 0 0 \%}$ \\
\hline
\end{tabular}

Source: Primary Data Processed, 2017
Shows that income of respondents who are mostly minimarket consumers has an income above> Rp. $3,000,000$ as many as 41 people $(41 \%)$, income between Rp. 2. 000.000 - Rp. 3.000 .000 as many as 34 people (34\%), income between $\mathrm{Rp}$. 1.000 .000 - Rp. 2.000 .000 are 22 people (22\%), and incomes below $<\mathrm{Rp} .1,000,000$ are 3 people $(3 \%)$.

\subsubsection{Multiple Linear Regression Analysis}

Multiple linear regression analysis is a form of analysis discusses extent of influence of independent variable $(\mathrm{X})$ on dependent variable (Y), where for variable (X1) is Service Quality, variable (X2) is Brand Image and (X3) is Customer Relationship Management and variable (Y) is customer loyalty. In calculating regression coefficient in this study using SPSS 17.0,results of regression calculation are as follows:

Table 7. Results of Multiple Linear Regression Coefficient Tests

\section{Coefficients $^{\mathrm{a}}$}

\begin{tabular}{|c|c|c|c|c|c|c|}
\hline \multirow[b]{2}{*}{ Model } & & \multirow{2}{*}{$\begin{array}{l}\text { Unstandardized } \\
\text { B }\end{array}$} & \multicolumn{2}{|r|}{$\begin{array}{l}\text { Standardized. } \\
\text { Coefficients }\end{array}$} & \multirow[b]{2}{*}{$\mathrm{t}$} & \multirow[b]{2}{*}{ Sig. } \\
\hline & & & Std. Error & Beta & & \\
\hline \multirow[t]{6}{*}{1} & (Constant) & 3.346 & 1.521 & & 2.199 & .030 \\
\hline & Service quality & .338 & .101 & .335 & 3.337 & .001 \\
\hline & Brand Image & .298 & .089 & .301 & 3.363 & .001 \\
\hline & Customer & .222 & .079 & .236 & 2.802 & .006 \\
\hline & Relationship & & & & & \\
\hline & Management & & & & & \\
\hline
\end{tabular}

a. Dependent Variable: Customer Loyalty

Source: Processed Data Primary (SPSS 17.0)

Table 7 show a about results of multiple linear regression coefficient test, it can be seen that linear regression equation is:

$Y=3,346+0,338 X_{1}+0,298 X_{2}+0,222 X_{3}$

Information:

$\mathrm{Y}=$ Customer. Loyalty
$\mathrm{X}_{1}=$ Serviced Quality

$\mathrm{X}_{2}=$ Brand Image

$\mathrm{X}_{3}=$ Customer Relationship Management

a) A constant of 3.346 states if Quality of service (X1), Brand Image (X2), and 
Customer Relationship Management (X3) values are constant (unchanged), then Customer Loyalty score (Y) is positive at 3.346 with a standard error of 1.521 .

b) Regression coefficient on variable Quality of service (X1) has a positive value on Customer Loyalty of 0.338 or $33.8 \%$ indicating Service Quality affects Customer Loyalty. If Quality of service score is increased by 1 unit, Customer Loyalty score will increase by 0.338 units with 0.101 standard error.

c) Regression coefficient on Brand Image variable (X2) has a positive value on Customer Loyalty of 0.298 or $29.8 \%$, indicating Brand Image affects Customer Loyalty. If Brand Imaged score is increased by one unit, Customer Loyalty score will increase by 0.298 units with a standard error of 0.089 .

d) Regression coefficient on variable Customer Relationship Management (X3) has a positive value on Customer Loyalty of 0.222 or $22.2 \%$ shows Customer Relationship Management affects Customer Loyalty. This means if Customer Relationship Management score is increased by 1 unit, Customer Loyalty score will increase by 0.222 units with a standard error of 0.079 .

\subsubsection{Validity Testing Results}

To test accuracy validity test is used, a gauge can reveal validity of a questionnaire. This research was tested using $n=100$ then $r$ table was 0.163 .

\section{Table 8. Validity Test Results}

\begin{tabular}{ccccc}
\hline Variable & Statement & $\mathbf{r}_{\text {count }}$ & $\mathbf{r}_{\text {table }}$ & Description \\
\hline \multirow{3}{*}{ Serviced Quality } & Statement 1 & 0.624 & 0,163 & valid \\
& Statement 2 & 0.637 & 0,163 & valid \\
& Statement 3 & 0.466 & 0,163 & valid \\
& Statement 4 & 0.507 & 0,163 & valid \\
& Statement 1 & 0.612 & 0,163 & valid \\
& Statement 2 & 0.709 & 0,163 & valid \\
Brand Image & Statement 3 & 0.580 & 0,163 & valid \\
& Statement 4 & 0.502 & 0,163 & valid \\
& Statement 1 & 0.348 & 0,163 & valid \\
& Statement 2 & 0.613 & 0,163 & valid \\
& Statement 3 & 0.615 & 0,163 & valid \\
& Statement 4 & 0.621 & 0,163 & valid \\
& Statement 1 & 0.526 & 0,163 & valid \\
Customer Loyalty & Statement 2 & 0.583 & 0,163 & valid \\
& Statement 3 & 0.555 & 0,163 & valid \\
& Statement 4 & 0.609 & 0,163 & valid \\
\hline
\end{tabular}

Source : Primary Data Processed (SPSS 17.0)

From calculations using SPSS 17.0 data were tested on 100 respondents stating all statements 116 for variable Quality of Service, Brand Image, CRM and Customer Loyalty are valid. This can be seen from results of calculations with table above, $r$ count $>r$ table $(0.163)$.

\subsubsection{Reliability Test Results}

The reliability test results for each variable obtained data as follows:

Table 9. Reliability Test Results 


\begin{tabular}{lccc}
\hline \multicolumn{1}{c}{ Variable } & $\begin{array}{c}\text { Cronbach's } \\
\text { Alpha }\end{array}$ & $\begin{array}{c}\text { Batas Cronbach's } \\
\text { Alpha }\end{array}$ & Description \\
\hline Service Quality & 0.757 & $>0,6$ & reliable \\
Brand Image & 0.789 & $>0,6$ & reliable \\
Customer Relationship & 0.747 & $>0,6$ & reliable \\
Management & & & \\
Customer Loyalty & 0.751 & $>0,6$ & reliable \\
\hline
\end{tabular}

Source: Primary Data Processed, 2017 (SPSS 17.0)

Table 9 shows Service Quality, Brand Image, CRM and Customer Loyalty have a Cronbach's alpha value above minimum Cronbach's alpha value $>0.6$ so it can be said all measuring concepts of each variable from questionnaire are reliable. This means that questionnaire used in this study is a reliable and reliable questionnaire.

\subsubsection{Model Feasibility Test F test}

To do F test can be seen in ANOVA table below as follows:

Table 10. Test Results F

\begin{tabular}{|c|c|c|c|c|c|c|}
\hline \multicolumn{7}{|c|}{ ANOVA $^{b}$} \\
\hline \multicolumn{2}{|c|}{ Model } & $\begin{array}{l}\text { Sum of } \\
\text { Squares }\end{array}$ & df & Mean Square & $\mathrm{F}$ & Sig. \\
\hline 1 & Regression & 183.143 & 3 & 61.048 & 32.271 & $.000^{\mathrm{a}}$ \\
\hline & Residual & 181.607 & 96 & 1.892 & & \\
\hline & Total & 364.750 & 99 & & & \\
\hline
\end{tabular}

a. Predictors: (Constant), CRM, Brand Image, Service Quality

b. Dependent Variable: Customer Loyalty

Source: Primary Data Processed (SPSS 17.0)

From above table ANOVA $\mathrm{f}$ test results can be explained that calculated $\mathrm{F}$ value of 32.272 with a significant $0,000 \mathrm{soH} 0$ is rejected. Thus variable Service Quality, Brand Image and CRM together have a positive and real effect on Customer Loyalty. This states regression model obtained is declared valid.

\subsubsection{Coefficient of Determination (R2)}

The output results are as follows:

Table 11. Determination Coefficient Test Results (R2)

\begin{tabular}{|ccc|}
\hline Model & $\mathrm{R}$ & R Square \\
\hline 1 & $.709^{\mathrm{a}}$ & .502 \\
\hline
\end{tabular}

a. Predictors: (Constant), CRM,

Brand Image, Customer Service

b. Dependent Variable: Customer Loyalty

Source: Data Processed 2017 (SPSS 17.0) 
The correlation coefficient $(\mathrm{R})$ of 0.709 and $\mathrm{R}$ square $0.502=50.2 \%$.coefficient of determination (R2) of $50.2 \%$ means $50.2 \%$ dependent variable of customer loyalty can be explained by independent variables namely Service Quality, Brand Image and Customer Relationship Management while remaining $49.8 \%$ is explained by other variables outside this study.

\subsubsection{Hypothesis Testing (t test)}

$\mathrm{t}$ test using coefficients analysis with SPSS processing obtained data as follows:

Tabel 12. Result $\mathrm{t}$

\begin{tabular}{|c|c|c|c|c|c|c|}
\hline \multicolumn{7}{|c|}{ Coefficients $^{\mathrm{a}}$} \\
\hline \multirow{2}{*}{\multicolumn{2}{|c|}{ Model }} & \multicolumn{2}{|c|}{$\begin{array}{l}\text { Unstandardized } \\
\text { Coefficients }\end{array}$} & \multirow{2}{*}{$\begin{array}{l}\text { Standardiz } \\
\text { ed } \\
\text { Coefficien } \\
\text { ts } \\
\text { Beta }\end{array}$} & \multirow[b]{2}{*}{$\mathrm{t}$} & \multirow[b]{2}{*}{ Sig. } \\
\hline & & $\mathrm{B}$ & Std. Error & & & \\
\hline \multirow[t]{4}{*}{1} & (Constant) & 3.346 & 1.521 & & 2.199 & .030 \\
\hline & Service Quality & .338 & .101 & .335 & 3.337 & .001 \\
\hline & Brand Image & .298 & .089 & .301 & 3.363 & .001 \\
\hline & $\begin{array}{l}\text { Customer } \\
\text { Relationship } \\
\text { Management }\end{array}$ & .222 & .079 & .236 & 2.802 & .006 \\
\hline & endent Variable: & mer Loy & ralty & & & \\
\hline
\end{tabular}

Source: Processed Data 2017 (SPSS 17,0) 
Table 12 can be explained that count Quality of service of 3.337 is at a significant value of 0.001 $<0.05$ then $\mathrm{H} 0$ is rejected. conclusion was rejecting $\mathrm{HO}$ and accepting $\mathrm{Ha}$ stated Quality of Service had a positive and significant effect on Customer Loyalty in 8 minimarket branches in Padurenan Village, East Bekasi.

The $t$ value of Brand Image of 3.363 is at a significant value of $0.001<0.05$ then $\mathrm{H} 0$ is rejected. Conclusion is rejecting $\mathrm{HO}$ and accepting $\mathrm{Ha}$ states Brand Imagery has a positive and significant influence on Customer Loyalty in 8 minimarket branches in Padurenan Village, East Bekasi.

The value of $t$ count CRM of 2.802 is at a significant value of $0.006<0.05$ then $\mathrm{H} 0$ is rejected. Conclusion was rejecting $\mathrm{HO}$ and accepting $\mathrm{Ha}$ stated CRM had a positive and significant effect on Customer Loyalty in 8 minimarket branches in Padurenan Village, East Bekasi.

5 Discussion

\subsection{Effect of Quality of Service on Customer Loyalty}

The research results, it can be seen there is a significant influence between Quality of service on Customer Loyalty in 8 minimarket branches in Padurenan Village, East Bekasi, meaning that Quality of Service can be used as a basis for predicting Customer Loyalty in 8 minimarket branches in Padurenan Village, East Bekasi. This shows Customer Loyalty in 8 minimarket branches in Padurenan Village, East Bekasi is influenced by Quality of service.

Based on Service Quality regression test (X1) regression coefficient on variable Service Quality (X1) has a positive value on Customer Loyalty of 0.338 or $33.8 \%$, indicating Service Quality affects Customer Loyalty. This means if Service Quality score is increased by 1 unit, Customer Loyalty score will increase by 0.338 units with a standard error of 0.101. $t$ test results show that significant value of Service Quality is $0.001<0.05$, which means Service Quality has a positive and significant effect on Customer Loyalty and average respondent agrees with Quality of Services provided by minimarket. Service Quality in service companies certainly affects Customer Loyalty.

The results of previous studies showed service quality simultaneously and partially influential on customer loyalty (Mulyaningsih, 2013).

\subsection{The Effect of Brand Image on Customer Loyalty}

There is a significant influence between Brand Image on Customer Loyalty in 8 minimarket branches in Padurenan Village, East Bekasi, meaning Brand Imaged can be used as a basis for predicting Customer Loyalty in 8 minimarket branches in Padurenan Village, East Bekasi. This shows Customer Loyalty in 8 branches of minimarket at Padurenan Urban Village, East Bekasi is influenced by Brand Image.

The regression coefficient on Brand Image variable (X2) has a positive value on Customer Loyalty of 0.298 or $29.8 \%$, indicating Brand Image affects Customer Loyalty. This means if Brand Image score is increased by 1 unit, Customer Loyalty score will increase by 0.298 units with a standard error of 0.089. $t$ test results showed that significant value of Brand Image of $0.001<0.05$ which means Brand Image has influence on customer loyalty and average respondent strongly agrees with Brand Image owned by the minimarket.

Previous studies have concluded Brand Image on customer loyalty has a positive influence (Aries Susanty and Najid Bangun Adi Saputra, 2011).

\subsection{The Influence of CRM on Customer Loyalty}

There is an influence between CRM on Customer Loyalty in 8 minimarket branches in Padurenan Village, East Bekasi, meaning CRM can be used as a basis for predicting Customer Loyalty in 8 mini market branches in Padurenan, East Bekasi. This shows Customer Loyalty in 8 minimarket branches in Padurenan Village, East Bekasi is influenced by CRM. 
The regression coefficient on variable CRM (X3) has a positive value on Customer Loyalty of 0.222 or $22.2 \%$ shows CRM affects Customer Loyalty. This means if CRM score is increased by 1 unit, Customer Loyalty score will increase by 0.222 units with a standard error of 0.079 . T test results indicate that value is significant CRM of 0.006 $<0.05$, which means CRM has a positive and significant effect on Customer Loyalty and average respondent respondents agree and are loyal to minimarket.

The results of previous studies stated there is a relationship and a positive and significant influence CRM on customer loyalty (Kalalo, 2013).

\section{Conclusion}

The conclusion of this research are:

1. Service Quality has an influence on Customer Loyalty in mini market at Padurenan Village, East Bekasi. Service Quality contributes greatly to Customer Loyalty due to Quality of Service provided by the mini market to its customers so customers become loyal to the mini market.

2. Brand Imager has an influence on Customer Loyalty in minimarket at Padurenan Village, East Bekasi. Brand Image is in minds of customers about mini market makes customers loyal to mini market.

3. CRM has an Influence on Customer Loyalty in mini market at Padurenan Village, East Bekasi. CRM helping customers to find out about CRM inform of mini market member cards. Mini market member Cards gives prizes to mini market members make members loyal to the mini market.

\section{References}

[1] Kalalo, Rini E. 2014. Customer Relationship Management dan Kualitas Pelayanan Pengaruhnya terhadap Loyalitas Konsumen PT. Matahari Dept. Store. Jurnal EMBA. Vol.1 No.4 hal. 1553-1561

[2] Adyhtyo, D., R., \& Mulyaningsih. 2013. Reliabilitas Mempengaruhi kepuasan pasien terhadap pelayanan kesehatan di salah satu puskesmas kabupaten Ngawi. Keperawatan, 10 (2).

[3] www.topbrand-award.com, Februari; 2017

[4] Tjiptono, Fandy dan Gregorius Chandra. 2005. Pemasaran Strategik. Yogyakarya: Andi.

[5] Buchari Alma, (2011), Manajemen Pemasaran dan Pemasaran Jasa, Cetakan Kesembelian, Alfabeth, Bandung.

[6] Ali, Hasan. 2009. Marketing Edisi Baru. Yogyakarta. Media Pressindo.

[7] Sugiyono. 2012. Metode Penelitian Kuantitatif Kualitatif dan R\&D. Bandung: Alfabeta.

[8] Ferdinand, Augusty. 2013. Metode Penelitian Manajemen. Semarang. Badan Penerbit Universitgas Diponegoro.

[9] Griffin, J. 1997. Customer Loyalty: How To Earn It, How To Keep It. McGraw Hill Irwin. New York. Terjemahan Dr. D.K. Yahya. 2005. Customer Loyalti :Menumbuhkan dan Mempertahankan Kesetiaan Pelanggan. Erlangga. Jakarta.

[10] Kotler, P dan G. Amstrong. 2008. Principles Of Marketing. $12^{\text {th }}$ ed. Prentice Hall International by Pearson Education. New Jersey. Terjemahan B. Sabran. 2014. Prinsip - prinsip Pemasaran. Edisi 12. Erlangga. Jakarta

[11] Kotler, P dan K.L. Keller. 2009. Marketing Management. $13^{\text {th }}$ ed. Pearson Education, Inc. New Jersey. Terjemahan H. Teguh, R.A. Rusli dan B. Molan. 2012. Manajemen Pemasaran. Edisi ke-13. PT. Indeks. Jakarta.

[12] Tjiptono, F. 2014. Pemasaran Jasa, Prinsip, Penerapan dan Penelitan. Andi Offset. Yogyakarta.

[13] Tjiptono, F. 2007. Strategi Pemasaran. Edisi Pertama. Andi Offset. Yogyakarta.

[14] Tjiptono, F. 2008. Service Management Mewujudkan Layanan Prima. CV Alfabeta. Bandung. 